\title{
ANALISIS KINERJA PEGAWAI MELALUI PENDEKATAN BALANCED SCORECARD PADA KANTOR SEKRETARIAT DAERAH KOTA DEPOK
}

\author{
Astri Susana Maharani ${ }^{1)}$ \\ Ignatius Jeffrey ${ }^{2)}$ \\ Augustina Kurniasih ${ }^{3)}$ \\ 1)Program Pascasarjana, Universitas Mercu Buana Jakarta \\ e-mail: astri_susana@yahoo.com \\ 2) Program Pascasarjana, Universitas Mercu Buana Jakarta \\ e-mail: ignatius.herobe@gmail.com \\ ${ }^{3)}$ Program Pascasarjana, Universitas Mercu Buana Jakarta \\ e-mail: augustina.kurniasih@gmail.com
}

\begin{abstract}
This study aims to analyze the performance of employees through the Balanced Scorecard approach consisting of four perspectives: financial, customer, internal business processes, and learning and descriptive growth perspective. The method used is literature search on a budget document called Laporan Akuntabilitas Kinerja Pemerintah (LAKIP) or Government Performance Accountability Report, of Regional Secretariat office Depok in 2012-2013. The budget document was prepared in April 2014 for the financial perspective, while the other three perspectives were made through questionnaires completed by 30 respondents from the work partners of Regional Secretariat Office of Depok City. While the questionnaires for internal business process perspective, and learning and growth perspective were filled out by 129 respondents from the employee of Regional Secretariat Office of Depok City. These questionnaires were prepared within the period of March-September 2014. Likert scale was used for variable measurement where a score of 1 was the lowest value and the highest value was a score of 5. Hypothesis testing was done by assessing the results of the answers on the understanding of work partners and employees, by understanding the value of the percentage. The result showed that the performance of the financial perspective was very good, and the performance of employees through customer perspective indicated employees produce services in accordance with their duties and functions was also very good, which was showed by as much as $85.65 \%$ of respondents agreed. Moreover, the internal business process perspective showed employee produces services in accordance with the Standard Operating Procedure (SOP) as well as the result of learning and growth perspective were very good, with the results of as much as $89.14 \%$ and 91.59\% of respondents agreed, respectively. These perspectives, hopefully will generate Balanced Scorecard framework that in turn, will provide inputs for the development of Human Resources (HR) at the office of the Regional Secretariat Depok.
\end{abstract}

Keywords: employee performance, perspective, balanced scorecard 


\section{PENDAHULUAN}

Kinerja instansi pemerintah di Indonesia tertuang dalam peraturan Instruksi Presiden Republik Indonesia Nomor 7 Tahun 1999 Tentang Akuntabilitas Kinerja Instansi Pemerintah (LAKIP) yaitu salah satunya dinyatakan bahwa dalam rangka lebih meningkatkan pelaksanaan pemerintah yang lebih berdaya guna, berhasil guna, bersih dan bertanggungjwab, dipandang perlu adanya pelaporan akuntabilitas kinerja instansi pemerintah untuk mengetahui kemampuannya dalam pencapaian visi, misi dan tujuan organisasi. LAKIP adalah satu-satunya pengukuran kinerja pada Instansi pemerintahan yang berbasis pada seberapa besar kinerja penyerapan anggaran. Berikut adalah daftar LAKIP Pemerintah Kabupaten/Kota di Provinsi Jawa Barat :

Tabel 1. Daftar Capaian Akuntabilitas Kinerja Kabupaten/Kota Pemerintah Se-Jawa Barat Tahun 2013

\begin{tabular}{|c|c|c|c|c|c|}
\hline No & Kab./Kota & Predikat & No & Kab./Kota & Predikat \\
\hline 1 & Kab. Bandung & $\mathrm{C}$ & 14 & Kab. Cianjur & $\mathrm{CC}$ \\
\hline 2 & Kab. Bandung Barat & $\mathrm{C}$ & 15 & Kab. Garut & $\mathrm{CC}$ \\
\hline 3 & Kab. Bekasi & $\mathrm{C}$ & 16 & Kab. Karawang & $\mathrm{CC}$ \\
\hline 4 & Kab. Cirebon & $\mathrm{C}$ & 17 & Kab. Purwakarta & $\mathrm{CC}$ \\
\hline 5 & Kab. Indramayu & $\mathrm{C}$ & 18 & Kab. Sukabumi & $\mathrm{CC}$ \\
\hline 6 & Kab. Kuningan & $\mathrm{C}$ & 19 & Kota Bandung & $\mathrm{CC}$ \\
\hline 7 & Kab. Majalengka & $\mathrm{C}$ & 20 & Kota Banjar & $\mathrm{CC}$ \\
\hline 8 & Kab. Subang & $\mathrm{C}$ & 21 & Kota Bekasi & $\mathrm{CC}$ \\
\hline 9 & Kab. Sumedang & $\mathrm{C}$ & 22 & Kota Bogor & $\mathrm{CC}$ \\
\hline 10 & Kab. Tasikmalaya & $\mathrm{C}$ & 23 & Kota Cimahi & $\mathrm{CC}$ \\
\hline 11 & Kota Tasikmalaya & $\mathrm{C}$ & 24 & Kota Cirebon & $\mathrm{CC}$ \\
\hline 12 & Kab. Bogor & $\mathrm{CC}$ & 25 & Kota Depok & $\mathrm{CC}$ \\
\hline 13 & Kab. Ciamis & $\mathrm{CC}$ & & & \\
\hline
\end{tabular}

Dari tabel 1. diketahui bahwa LAKIP Pemerintah Kota Depok berkinerja kurang baik. Apabila suatu organisasi berkinerja kurang baik maka dapat dinilai pula bahwa kinerja pegawainya sudah pasti kurang baik, karena organisasi dihidupkan dan dibergerakan oleh SDM yang ada didalamnya. Selama ini pengukuran kinerja instansi pemerintah hanya berdasarkan pada LAKIP yang mengukur perspektif finansial saja, namun jika dimasukkan kedalam matriks pendekatan Balanced Scorecard perspektif lain seperti perspektif pelanggan, perspektif proses bisnis internal serta perspektif pertumbuhan dan pembelajaran tidak ada. Selain itu, format pelaporan LAKIP belum melakukan pengukuran terhadap indikator-indikator kinerja lainnya yang lebih bersifat intangible atau non teknis namun secara langsung maupun tidak sangat mempengaruhi kinerja organisasi maupun kinerja pegawai pemerintah secara keseluruhan. Tabel 2 berikut menunjukkan bahwa selama ini pengukuran kinerja pada sektor publik hanya menggunakan pengukuran keuangan, belum ada pengukuran kinerja untuk pegawai. 
Tabel 2. Matriks Program-Program LAKIP pada Pendekatan Balanced Scorecard

\begin{tabular}{lcccc}
\hline \multicolumn{1}{c}{ Program-program dalam Penilaian } \\
LAKIP & $\begin{array}{c}\text { Perspektif } \\
\text { Pelanggan }\end{array}$ & $\begin{array}{c}\text { Perspektif } \\
\text { Proses Bisnis } \\
\text { Internal }\end{array}$ & $\begin{array}{c}\text { Perspektif Pertum- } \\
\text { buhan dan Pembe- } \\
\text { lajaran }\end{array}$ & $\begin{array}{c}\text { Perspektif } \\
\text { Keuangan }\end{array}$ \\
\hline $\begin{array}{l}\text { Meningkatkan pengetahuan/keterampilan } \\
\text { kesejahteraan aparatur dan masyarakat }\end{array}$ & $\mathrm{X}$ & $\mathrm{X}$ & $\mathrm{X}$ & $\mathrm{V}$ \\
$\begin{array}{l}\text { Meningkatnya peran agama dan masyara- } \\
\text { kat/dunia usaha }\end{array}$ & $\mathrm{X}$ & $\mathrm{X}$ & $\mathrm{X}$ & $\mathrm{V}$ \\
$\begin{array}{l}\text { Terciptanya pelayanan yang lebih efisien, } \\
\text { efektif dan transparan }\end{array}$ & $\mathrm{X}$ & $\mathrm{X}$ & $\mathrm{X}$ & $\mathrm{V}$ \\
$\begin{array}{l}\text { Meningkatnya kualitas manajemen } \\
\text { pemerintahan }\end{array}$ & $\mathrm{X}$ & $\mathrm{X}$ & $\mathrm{X}$ & $\mathrm{V}$ \\
$\begin{array}{l}\text { Meningkatnya peran perangkat daerah } \\
\text { dalam pengkoordinasian tugas dan fung- } \\
\text { sinya }\end{array}$ & $\mathrm{X}$ & $\mathrm{X}$ & $\mathrm{X}$ & $\mathrm{V}$ \\
$\begin{array}{l}\text { Meningkatnya kualitas kelembagaan dan } \\
\text { ketatalaksanaan }\end{array}$ & $\mathrm{X}$ & $\mathrm{X}$ & $\mathrm{X}$ & $\mathrm{V}$ \\
$\begin{array}{l}\text { Tersedianya rekomendasi dan dokumen } \\
\text { kebijakan Pemerintah Kota }\end{array}$ & $\mathrm{X}$ & $\mathrm{X}$ & $\mathrm{X}$ & $\mathrm{V}$ \\
\hline
\end{tabular}

(Sumber : Hasil olahan penulis, 2014)

Rumusan masalah yang diajukan dalam penelitian ini menggunakan pendekatan Balanced Scorecard pada kantor Sekretariat Daerah Kota Depok terangkum dalam beberapa pertanyaan berikut: 1) Dalam perspektif keuangan, apakah pelaksanaan anggaran Kantor Sekertariat Daerah telah terlaksana sesuai dengan sasaran program LAKIP?; 2) Dalam perspektif pelanggan, apakah pegawai menghasilkan produk (layanan jasa) sesuai dengan tugas pokok dan fungsi?; 3) Dalam perspektif proses bisnis internal, apakah pegawai dapat menghasilkan produk (layanan jasa) sesuai dengan SOP yang telah ditentukan?; 4) Dalam perspektif pertumbuhan dan pembelajaran, apakah pegawai dapat menghasilkan produk (layanan jasa) sesuai dengan tujuan visi dan misi kantor?; 5) Apakah kerangka kerja Balanced Scorecard dapat memberikan masukan-masukan bagi pengembangan Sumber Daya Manusia (SDM) pada kantor Sekertariat Daerah Kota Depok setelah dilakukan penelitian?

Batasan masalah dalam penelitian ini adalah meliputi: 1) Obyek pengukuran kinerja dalam perspektif pelanggan berkaitan dengan pelayanan yang merujuk pada pelaksanaan tugas pokok dan fungsi pegawai yaitu mitra kerja Sekertariat Daerah Kota Depok; 2) Obyek pengukuran kinerja dalam perspektif proses bisnis internal serta perspektif pertumbuhan dan pembelajaran berkaitan dengan pelaksanaan dalam SOP serta perwujudan visi dan misi yaitu pegawai Sekertariat Daerah; 3) Obyek pengukuran kinerja dalam perspektif keuangan yaitu menganalisis kinerja keuangan dalam rentang waktu 2012- 2013.

Berdasar Keputusan Menteri Dalam Negeri dan Otonomi Daerah Nomor 50 Tahun 2000 tentang Pedoman Susunan Organisasi Tata Kerja Perangkat Daerah, dalam menjalankan keberlangsungan pemerintahan daerah, pelaksanaan organisasi pemerintah daerah dilaksanakan 
oleh unit-unit organisasi pemerintah daerah yang disebut Organisasi Perangkat Daerah (OPD). Sekertariat Daerah Kota Depok adalah salah satu unsur Organisasi Perangkat Daerah (OPD). Berdasar Peraturan Daerah Kota Depok Nomor 8 Tahun 2008 tentang Organisasi Perangkat Daerah dibentuklah Sekretariat Daerah Kota Depok. Sekretariat Kota Depok Setiap OPD beserta unsur didalamnya memiliki visi "Terwujudnya Reformasi Birokrasi melalui Pelayanan Kesekretariatan yang Profesional. Sedangkan misinya adalah 1) Meningkatkan kualitas sumber daya manusia yang profesional dan religius secara berkelanjutan; 2) Meningkatkan kualitas pelayanan administrasi keseketariatan; 3) Meningkatkan sinergitas tugas dan fungsi perangkat daerah; 4) Melaksanakan kelembagaan dan ketatalaksanaan yang efektif dan efisien; 5) Mewujudkan perumusan kebijakan pemerintah kota.

Dengan tantangan bisnis yang dihadapi, Sekertariat Daerah Kota Depok menyusun sasaran program yang disesuaikan dengan RPJMD Kota Depok Tahun 2011-2016 yaitu: 1) Meningkatnya pengetahuan atau keterampilan dan kesejahteraan aparatur dan masyarakat; 2) Meningkatnya peran agama dan masyarakat/dunia usaha; 3) Meningkatnya pemahaman keagamaan bagi aparatur dan masyarakat; 4) Terciptanya pelayanan yang efisien, efektif, dan transparan; 5) Meningkatnya kualitas manajemen pemerintah; 6) Meningkatnya peran perangkat daerah dalam pengkoordinasian tugas dan fungsinya; 7) Meningkatnya kualitas kelembagaan dan ketatalaksanaan; 8) Tersedianya Rekomendasi dan Dokumentasi Kebijakan Pemerintah Kota.

\section{TINJAUAN PUSTAKA}

Mahsun (2009) dan Body et al. (2008) menyatakan bahwa kinerja juga diterjemahkan sebagai suatu gambaran mengenai tingkat pencapaian pelaksanaan suatu kegiatan/program/ kebijakan dalam mewujudkan sasaran, tujuan, visi dan misi organisasi yang tertuang dalam strategic planning suatu organisasi. Mahmudi (2010) menyatakan bahwa kinerja merupakan suatu konstruk yang bersifat multidimensional, pengukurannya juga bervariasi tergantung pada kompleksitas faktor-faktor yang membentuk kineja.

Verica et.al. (2012) dan Federica and James (2008) menyatakan bahwa penilaian kinerja adalah usaha untuk membantu merencanakan dan mengontrol proses pengelolaan pekerjaan sehingga dapat dilaksanakan sesuai dengan tujuan yang telah ditetapkan organisasi.

Mahmudi (2010) dan Northcott (2012) menyatakan bahwa penilaian kinerja merupakan suatu proses penilaian kemajuan pekerjaan terhadap pencapaian tujuan dan sasaran yang telah ditentukan, termasuk informasi atas efisiensi penggunaan sumber daya dalam menghasilkan barang atau jasa, kualitas barang atau jasa, perbandingan hasil kerja dengan target dan efektivitas tindakan dalam mencapai tujuan.

Karakteristik Balanced Scorecard Kaplan dan Norton (2004), Mei (2013), Manville (2007), Malzt et al. (2004) menyebutkan bahwa Balanced Scorecard merupakan sebuah sistem manajemen untuk mengimplementasikan strategi, mengukur kinerja yang tidak hanya dari sisi finansial semata melainkan juga melibatkan sisi non finansial, serta untuk mengkomunikasikan visi, strategi, dan kinerja yang diharapkan. Dengan kata lain pengukuran kinerja tidak dilakukan semata-mata untuk jangka pendek saja, tetapi juga untuk jangka panjang. 


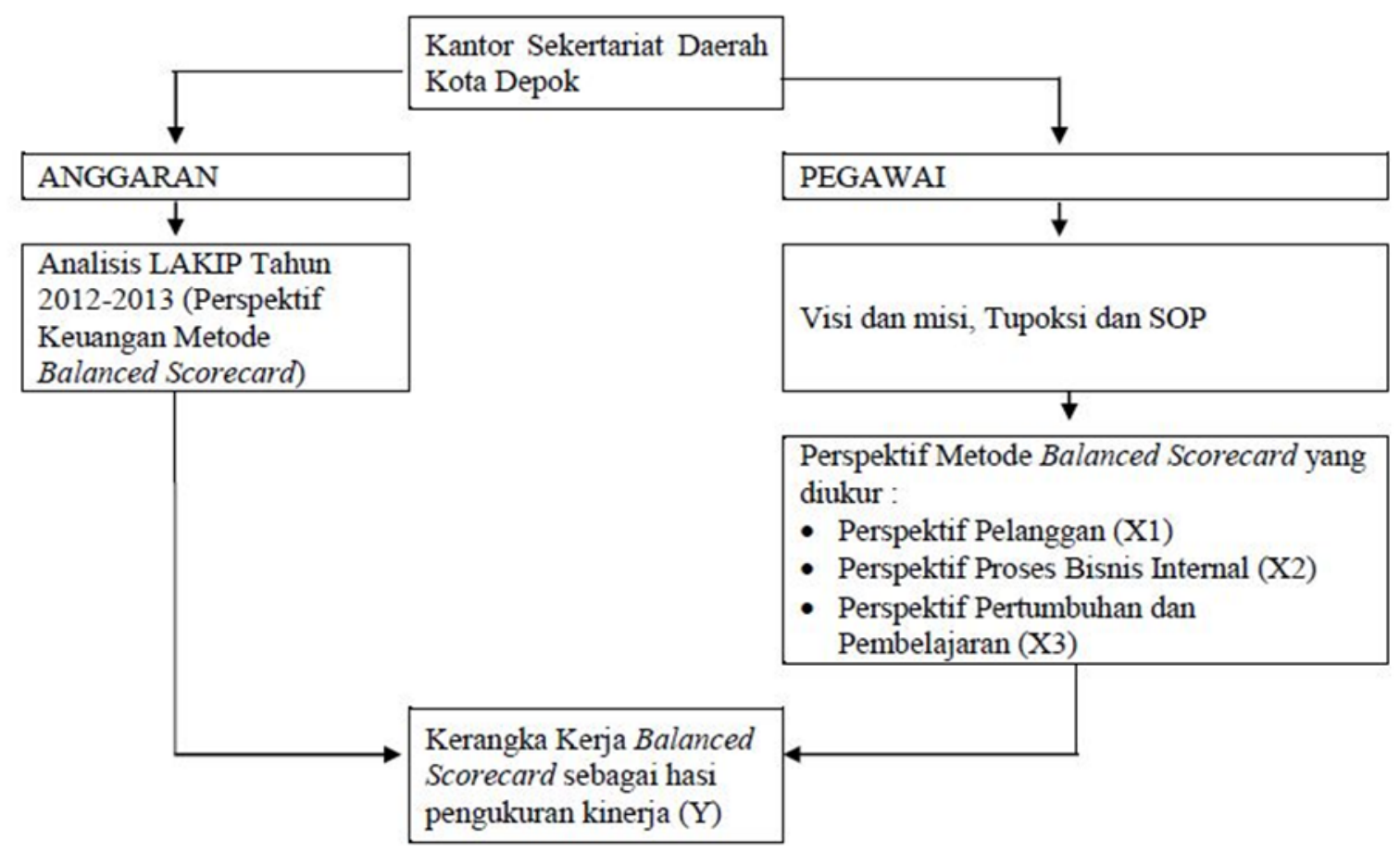

\section{Gambar 1. Kerangka Pemikiran}

Berdasarkan kerangka pemikiran di atas maka hipotesis penelitian adalah sebagai berikut: 1) Dalam perspektif keuangan pelaksanaan anggaran Kantor Sekertariat Daerah telah terlaksana sesuai dengan sasaran program LAKIP; 2) Dalam perspektif pelanggan pegawai menghasilkan layanan jasa sesuai dengan tugas pokok dan fungsi; 3) Dalam perspektif proses bisnis internal pegawai menghasilkan layanan jasa sesuai dengan SOP; 4) Dalam perspektif pertumbuhan dan pembelajaran pegawai dapat menghasilkan layanan jasa sesuai dengan tujuan visi dan misi kantor; 5) Kerangka kerja Balanced Scorecard diharapkan dapat memberikan masukan-masukan bagi pengembangan SDM pada kantor Sekertariat Daerah Kota Depok.

\section{METODE PENELITIAN}

\section{Jenis penelitian}

Penelitian ini termasuk kedalam jenis pendekatan kuantitatif. Data yang dipelajari adalah data primer dan sekunder yang diambil dari objek penelitian tersebut. Penelitian ini juga menggunakan metode deskriptif analitis. Penelitian deskriptif adalah salah satu jenis penelitian yang tujuannya untuk menyajikan gambaran lengkap mengenai setting sosial atau dimaksudkan untuk eksplorasi dan klarifikasi mengenai suatu fenomena atau kenyataan sosial, dengan jalan mendeskripsikan sejumlah variabel yang berkenaan dengan masalah dan unit yang diteliti antara fenomena yang diuji.

\section{Populasi dan sampel}

Perspektif Keuangan yaitu Laporan Akuntabilitas Kinerja Instansi Pemerintah (LAKIP) Tahun 2012-2013 yang disiapkan pada bulan Maret 2014. Perspektif pelanggan yaitu 30 responden berasal dari mitra kerja menggunakan teknik purposive sampling, yaitu teknik 
penentuan sampel dengan pertimbangan tertentu (Sugiyono, 2010 a). Perspektif bisnis internal serta Pertumbuhan dan pembelajaran yaitu 190 responden berasal dari pegawai menggunakan teori Slovin dengan toleransi kesalahan 5\% yaitu menjadi 129 responden menggunakan teknik proportionate stratified random sampling dikarenakan populasi pegawai Sekretariat Daerah Kota Depok yang tidak homogen dan berstrata secara porposional (Sugiyono, 2010 $)$. Untuk perspektif pelanggan, perspektif proses bisnis internal serta perspektif pertumbuhan dan pembelajaran disiapkan pada rentang waktu bulan Maret-September 2014.

\section{Teknik Analisis Data}

\section{Uji Validitas}

Kriteria yang digunakan untuk menyatakan valid atau tidak valid adalah bila koefisien korelasi $r_{\text {hitung }}>r_{\text {table }}$ dan nilai $r$ positif dengan tingkat signifikansi 5\%, berarti butir pertanyaan tersebut valid. Untuk tiap butir $r$ hitung dapat dilihat pada kolom corrected item-total correlation. Kuesioner diujikan kepada 30 responden.

\section{Uji Reliabilitas}

Mengetahui tingkat konsistensi jawaban tetap atau konsisten untuk diujikan kapan saja instrumen tersebut disajikan. Suatu kuesioner dikatakan reliable apabila nilai koefisien Alpha Cronbach $>0,7$ (Sugiyono, 2010 ). Untuk memudahkan melakukan pengujian validitas dan realibilitas peneliti menggunakan alat bantu software yaitu SPSS 17.

Tahapan selanjutnya adalah: 1) Kuisioner disebarkan secara random sampling ke 30 mitra kerja dan 129 pegawai; 2) Menghitung skor mentah dari setiap jawaban; 3) Mengubah skor mentah ke dalam bentuk nilai prosentase; 4) Menilai pemahaman mitra kerja dan pegawai berdasarkan pemahaman nilai \%; 5) Mendiagnosis pola jawaban dan mengkategorikan; 6) Menganalisis skor jawaban berdasarkan kategori pemahaman

Menentukan skala pada masing-masing olahan data:

1. Skala pengukuran kinerja keuangan

Skala penyerapan anggaran ditentukan sesuai dengan pedoman LAKIP sebagai berikut:
a. $<55 \%=$ kurang baik
b. $55 \%-70 \%=$ sedang
c. $70 \%-85 \%=$ baik
d. $85 \%-100 \%=$ sangat baik

2. Skala pengukuran kuesioner

Pengukuran kuesioner untuk perspektif pelanggan, proses bisnis internal, dan pertumbuhan dan pembelajaran menggunakan skala likert dengan lima tingkat penilaian.

Tabel 3. Skala Pengukuran Kuesioner

\begin{tabular}{cc}
\hline Kelas Interval & Keterangan \\
\hline $1,00-1,80$ & Sangat tidak puas/Sangat tidak setuju \\
$1,81-2,60$ & Tidak puas/tidak setuju
\end{tabular}




\begin{tabular}{cc}
$2,61-3,40$ & Cukup puas/cukup setuju \\
$3,41-4,20$ & Puas/setuju \\
$4,21-5,00$ & Sangat puas/setuju \\
\hline
\end{tabular}

(Sumber : Hasil olahan penulis, 2014)

Interpretasi skor untuk menganalisis dan mengkategorikan hasil jawaban dengan rentang skor dan kriteria:

1. $0 \%-20 \%$ : Sangat lemah

2. $21 \%-40 \%$ : Lemah

3. $41 \%-60 \%$ : Cukup

4. $61 \%-80 \%$ : Kuat

5. $81 \%-100 \%$ : Sangat kuat

\section{HASIL DAN PEMBAHASAN}

\section{Perspektif Keuangan}

Rata-rata capaian kinerja keuangan Sekertariat Daerah Kota Depok dengan $\mathbf{r}=\mathbf{0 , 9 9} \%$ apabila dimasukkan dalam skala pedoman LAKIP diperoleh hasil yaitu sangat baik dengan diperoleh hasil pada tabel 1.4, sehingga Sekertariat Daerah Kota Depok perlu mempertahankan kinerja keuangan atau lebih meningkatkan kinerja keuangan di tahun yang akan datang.

Tabel. 4. Perbandingan Data Capaian Kinerja Keuangan Sekretariat Daerah Kota Depok Tahun 2012-2013

\begin{tabular}{|c|c|c|c|c|c|c|c|}
\hline \multicolumn{2}{|c|}{ Sasaran } & \multicolumn{2}{|c|}{ Target } & \multicolumn{2}{|c|}{ Realisasi } & \multicolumn{2}{|c|}{ Capaian (\%) } \\
\hline Uraian & Indikator Kinerja & 2012 & 2013 & 2012 & 2013 & 2012 & 2013 \\
\hline $\begin{array}{l}\text { Meningkatkan } \\
\text { pengetahuan/keter- } \\
\text { ampilan kesejahter- } \\
\text { aan aparatur dan } \\
\text { masyarakat }\end{array}$ & $\begin{array}{l}\text { Aparatur dan } \\
\text { masyarakat yang } \\
\text { mengikuti pendi- } \\
\text { dikan, pelatihan, } \\
\text { bimbingan teknis, } \\
\text { sosialisasi, dll }\end{array}$ & $50 \%$ & $60 \%$ & $50 \%$ & $60 \%$ & $100 \%$ & $100 \%$ \\
\hline $\begin{array}{l}\text { Meningkatnya peran } \\
\text { agama dan masyara- } \\
\text { kat / dunia usaha }\end{array}$ & $\begin{array}{l}\text { Keswadayaan } \\
\text { masyarakat }\end{array}$ & $100 \%$ & $100 \%$ & $100 \%$ & $100 \%$ & $100 \%$ & $100 \%$ \\
\hline $\begin{array}{l}\text { Meningkatnya pema- } \\
\text { haman keagamaan } \\
\text { bagi aparatur dan } \\
\text { masyarakat }\end{array}$ & $\begin{array}{l}\text { Aparatur dan } \\
\text { masyarakat yang } \\
\text { mengikuti kegiatan } \\
\text { keagamaan }\end{array}$ & $70 \%$ & $70 \%$ & $70 \%$ & $69,61 \%$ & $100 \%$ & $96,59 \%$ \\
\hline $\begin{array}{l}\text { Terciptanya pelay- } \\
\text { anan yang lebih } \\
\text { efisien, efektif dan } \\
\text { transparan }\end{array}$ & $\begin{array}{l}\text { Indeks Kepuasan } \\
\text { Masyarakat }\end{array}$ & $79,45 \%$ & $79,60 \%$ & $46,12 \%$ & $54,77 \%$ & $58,04 \%$ & $68,81 \%$ \\
\hline $\begin{array}{l}\text { Meningkatnya } \\
\text { kualitas manajemen } \\
\text { pemerintahan }\end{array}$ & $\begin{array}{l}\text { Jumlah kerjasama } \\
\text { daerah yang ter- } \\
\text { jalin }\end{array}$ & $\begin{array}{l}4 \text { keg- } \\
\text { iatan }\end{array}$ & $\begin{array}{l}4 \mathrm{keg}- \\
\text { iatan }\end{array}$ & $\begin{array}{l}2 \mathrm{keg}- \\
\text { iatan }\end{array}$ & $\begin{array}{l}4 \mathrm{keg}- \\
\text { iatan }\end{array}$ & $50 \%$ & $100 \%$ \\
\hline
\end{tabular}




\begin{tabular}{|c|c|c|c|c|c|c|c|}
\hline $\begin{array}{l}\text { Meningkatnya peran } \\
\text { perangkat daerah } \\
\text { dalam pengkoor- } \\
\text { dinasian tugas dan } \\
\text { fungsinya }\end{array}$ & $\begin{array}{l}\text { Terciptanya sink- } \\
\text { ronisasi tugas dan } \\
\text { fungsi perangkat } \\
\text { daerah }\end{array}$ & $70 \%$ & $70 \%$ & $70 \%$ & $70 \%$ & $100 \%$ & $100 \%$ \\
\hline $\begin{array}{l}\text { Meningkatnya kuali- } \\
\text { tas kelembagaan dan } \\
\text { ketatalaksanaan }\end{array}$ & $\begin{array}{l}\text { Terciptanya } \\
\text { organisasi perang- } \\
\text { kat daerah yang } \\
\text { berkualitas sesuai } \\
\text { dengan PP No.14 } \\
\text { tahun } 2007\end{array}$ & $80 \%$ & $80 \%$ & $81,48 \%$ & $80 \%$ & $101,85 \%$ & $100 \%$ \\
\hline $\begin{array}{l}\text { Tersedianya reko- } \\
\text { mendasi dan } \\
\text { dokumen kebijakan } \\
\text { Pemerintah Kota }\end{array}$ & $\begin{array}{l}\text { Jumlah Perda yang } \\
\text { dihasilkan }\end{array}$ & $\begin{array}{l}11 \text { rap- } \\
\text { erda }\end{array}$ & $\begin{array}{l}12 \text { rap- } \\
\text { erda }\end{array}$ & $\begin{array}{l}20 \text { rap- } \\
\text { erda }\end{array}$ & $\begin{array}{l}17 \text { rap- } \\
\text { erda }\end{array}$ & $181,82 \%$ & $141,67 \%$ \\
\hline
\end{tabular}

(Sumber : Lakip Sekertariat Daerah Kota Depok TA. 2013/Bagian Keuangan)

(Sumber : Data LAKIP Sekretariat Daerah Kota Depok)

Analisis kinerja manajerial perspektif keuangan yaitu strategi pemecahan masalah yang dilaksanakan Sekertariat Daerah Kota Depok di tahun mendatang untuk memperbaiki kinerjanya melalui kegiatan yang dilaksanakan di antaranya:

a. Mengoptimalkan proses perencanaan anggaran, sehingga dapat meminimalisir kesalahan dalam proses perencanaan anggaran.

b. Menganggarkan kembali kegiatan-kegiatan yang belum terealisasi yang masih relevan untuk dilaksanakan ditahun berikutnya.

c. Meningkatkan koordinasi antar bagian, OPD lain, Pemerintah Propinsi Jawa Barat dan Pemerintah Pusat.

d. Mengoptimalkan pelaksanaan monitoring dan evaluasi kegiatan-kegiatan dilingkup Sekertariat Daerah Kota Depok, sehingga dapat diketahui keberhasilan, kegagalan maupun keberlanjutan suatu kegiatan.

\section{Perspektif Pelanggan}

Analisis perspektif pelanggan dilakukan dengan mengukur tingkat kepuasan pelanggan dengan menggunakan teori service quality yang diperkenalkan oleh Parasuraman et.al (2010). Teori tersebut menyebutkan bahwa kualitas layanan dibagi menjadi lima dimensi yaitu tangibility, reliability, responsiveness, assurance, dan empathy.

Tabel 5. Rangkuman Hasil Tanggapan Responden Berdasarkan Dimensi pada Perspektif Pelanggan

\begin{tabular}{|c|c|c|c|c|c|c|c|}
\hline \multirow{2}{*}{ No } & \multirow{2}{*}{ Dimensi } & \multicolumn{5}{|c|}{ Presentase Jawaban } & \multirow{2}{*}{$\mathrm{N}$} \\
\hline & & SP & $\mathrm{P}$ & $\mathrm{CP}$ & $\mathrm{TP}$ & STP & \\
\hline 1 & Tangibles/bukti fisik & $16,67 \%$ & $38,33 \%$ & $20,00 \%$ & $16,67 \%$ & $8,33 \%$ & $100,00 \%$ \\
\hline 2 & Reliability/kehandalan & $39,26 \%$ & $32,22 \%$ & $15,55 \%$ & $7,41 \%$ & $5,56 \%$ & $100,00 \%$ \\
\hline 3 & Responsiveness/ketanggapan & $32,50 \%$ & $34,17 \%$ & $16,67 \%$ & $11,66 \%$ & $5,00 \%$ & $100,00 \%$ \\
\hline
\end{tabular}




\begin{tabular}{cccccccc}
4 & Assurance/jaminan & $48,67 \%$ & $21,33 \%$ & $15,67 \%$ & $8,00 \%$ & $6,34 \%$ & $100,01 \%$ \\
5 & Empathy/perhatian & $45,33 \%$ & $30,67 \%$ & $10,00 \%$ & $9,33 \%$ & $5 \%$ & $100,00 \%$ \\
\hline & $182,43 \%$ & $156,72 \%$ & $77,89 \%$ & $53,07 \%$ & $29,90 \%$ & $500,01 \%$ \\
\hline & $36,49 \%$ & $31,34 \%$ & $15,58 \%$ & $10,61 \%$ & $5,98 \%$ & $100 \%$ \\
\hline
\end{tabular}

( sumber : hasil olahan penulis, 2014)

Hasil penelitian dapat disimpulkan bahwa pada hasil tanggapan responden mengenai perspektif pelanggan yaitu mitra kerja pada kantor Sekertariat Daerah Kota Depok dinyatakan bahwa pelayanan yang diberikan pegawai kantor Sekertariat Kota Depok sudah memberikan pelayanan yang baik dan memuaskan mitra kerja dalam memenuhi keinginan masyarakat dalam memperoleh produk layanan jasa sesuai dengan tugas pokok dan fungsi pegawai pada bagian kantor Sekertariat Daerah Kota Depok.

Analisis kinerja manajerial pada perspektif pelanggan yaitu merupakan usaha untuk mendorong pertumbuhan dengan mengaitkan keseluruhan organisasi dengan lingkungannya. Dimana setiap orang dalam organisasi itu ingin berkembang tetapi sumber perkembangan dan pertumbuhan itu sulit dipahami, analisis kinerja tersebut terdiri atas tiga komponen yaitu:

a. Achieve market focus, strategi memfokuskan pada pasar merupakan usaha untuk menghubungkan pola pikir organisasi secara keseluruhan pada lingkungannya. Sistem memusatkan pada kepentingan pelanggan ( konsumen ) sehingga membawa pertumbuhan organisasi.

b. Invent new business, strategi menemukan bisnis baru, merupakan strategi untuk membangun kemampuan organisasi melalui pendekatan kemitraan, merger dan akuisisi dan melalui strategy ini diharapkan membawa kehidupan baru bagi organisasi.

c. Change the rules through information technology, pendekatan merubah aturan melalui tehnology informasi. Merupakan usaha memanfaatkan teknologi sebagai dasar untuk mencapai jalan baru dalam menghadapi kompetisi. Melalui teknologi dapat menghubungkan berbagai unit organisasi sehingga dapat mengintegrasikan informasi dan proses pengambilan keputusan. Tehnology dapat meningkatkan efisiensi dan arus informasi dari lingkungan organisasi terutama sebagai usaha peningkatan kinerja pegawai kantor Sekertariat Daerah Kota Depok secara berkelanjutan.

\section{Perspektif Proses Bisnis Internal}

Analisis perspektif proses bisnis internal dilakukan melalui Keputusan Menteri Pendayaan Aparatur Negara MenPAN Nomor 63 Tahun 2003 mengenai rambu-rambu pemberian pelayanan birokrasi publik kepada masyarakat secara baik. Berbagai prinsip proses bisnis internal yang sesuai dengan standar oerasional prosedur tersebut dibagi menjadi 10 dimensi yaitu kesederhanaan, kejelasan, kepastian, akurasi, kesamaan, tanggung jawab, kelengkapan, sarana dan prasarana, kemudahan akses, kedisiplinan, kesopanan dan keramahan serta kenyamanan. 
Tabel 6. Rangkuman Hasil Tanggapan Responden Berdasarkan Dimensi pada Perspektif Proses Bisnis Internal

\begin{tabular}{|c|c|c|c|c|c|c|c|}
\hline \multirow{2}{*}{ No } & \multirow{2}{*}{ Dimensi } & \multicolumn{5}{|c|}{ Presentase Jawaban } & \multirow{2}{*}{$\mathbf{N}$} \\
\hline & & SS & $\mathbf{S}$ & CS & TS & STS & \\
\hline 1 & Kesederhanaan & $23,26 \%$ & $37,98 \%$ & $22,48 \%$ & $11,11 \%$ & $5,17 \%$ & $100,00 \%$ \\
\hline 2 & Kejelasan & $21,71 \%$ & $34,10 \%$ & $32,17 \%$ & $9,69 \%$ & $2,33 \%$ & $100,00 \%$ \\
\hline 3 & Kepastian & $23,64 \%$ & $35,66 \%$ & $25,19 \%$ & $13,18 \%$ & $2,33 \%$ & $100,00 \%$ \\
\hline 4 & Akurasi & $33,33 \%$ & $34,88 \%$ & $16,67 \%$ & $12,40 \%$ & $2,72 \%$ & $100,00 \%$ \\
\hline 5 & Kesamaan & $23,64 \%$ & $44,18 \%$ & $20,93 \%$ & $10,47 \%$ & $0,78 \%$ & $100,00 \%$ \\
\hline 6 & Tanggung jawab & $22,22 \%$ & $47,03 \%$ & $20,93 \%$ & $9,82 \%$ & $0,00 \%$ & $100,00 \%$ \\
\hline 7 & $\begin{array}{l}\text { Kelengkapan saraba dan } \\
\text { prasarana pelayanan }\end{array}$ & $18,61 \%$ & $43,41 \%$ & $29,07 \%$ & $5,03 \%$ & $3,88 \%$ & $100,00 \%$ \\
\hline 8 & Kemudahan akses pelayanan & $29,72 \%$ & $35,91 \%$ & $24,81 \%$ & $7,49 \%$ & $2,07 \%$ & $100,00 \%$ \\
\hline 9 & $\begin{array}{l}\text { Kedisiplinan, kesopanan dan } \\
\text { keramahan }\end{array}$ & $25,84 \%$ & $45,22 \%$ & $23,25 \%$ & $4,91 \%$ & $0,78 \%$ & $100,00 \%$ \\
\hline \multirow[t]{3}{*}{10} & Kenyamanan pelayanan & $27,13 \%$ & $49,09 \%$ & $16,54 \%$ & $5,95 \%$ & $1,29 \%$ & $100,00 \%$ \\
\hline & & $249,10 \%$ & $407,46 \%$ & $232,04 \%$ & $90,05 \%$ & $21,35 \%$ & $1000,00 \%$ \\
\hline & Jumlah & $24,91 \%$ & $40,75 \%$ & $23,20 \%$ & $9,01 \%$ & $2,14 \%$ & $100,00 \%$ \\
\hline
\end{tabular}

(sumber : hasil olahan penulis, 2014)

Hasil penelitian dapat dinyatakan bahwa sebagian besar pegawai kantor Sekertariat Daerah Kota Depok setuju bahwa perspektif proses bisnis internal menghasilkan produk layanan jasa sesuai dengan SOP yang berlaku bagai PNS seluruh Indonesia sesuai amanat reformasi birokrasi.

Analisis kinerja manajerial pada perspektif proses bisnis internal terkait organisasi meliputi investasi SDM (Sumber Daya Manusia) sehingga SDM mempunyai keahlian dan kemampuan baru untuk tercapainya tujuan organisasi. Strategi pembaharuan merupakan kekuatan yang penting dalam dimensi transformasi organisasi, ada 3 komponen yang meliputi:

a. Menciptakan struktur reward (create a reward structure), strategi ini merupakan unsur memotivasi pegawai, reward system sangat penting bagi usaha untuk menciptakan semangat kerja produktivitas pegawai dan kinerja organisasi secara keseluruhan , artinya apabila reward system tidak sejalan dengan sasaran organisasi maka system tersebut tidak akan produktif terhadap usaha untuk meningkatkan kinerja dan produktivitas organisasi.

b. Membangun individu yang belajar (build individual learning). Suatu organisasi harus mempunyai komitmen untuk mengembangkan individu dalam meningkatkan keahlian, kemampuan dan ketrampilan melalui berbagai proses belajar.

c. Pengembangan organisasi (develop the organization). Sistem manajerial intern/sistem manajerial pegawai dapat dipastikan berkembang dan berkelanjutan.

\section{Perspektif Pertumbuhan dan Pembelajaran}

Pengukuran kinerja suatu organisisai dengan memperhatikan perspektif pembelajaran dan pertumbuhan dimaksudkan agar organisasi dapat menjadi suatu organisai yang mampu 
melakukan perbaikan secara terus menerus dan menciptakan pertumbuhan secara berkelanjutan. Dalam penelitian ini, perspektif pembelajaran dan pertumbuhan diukur dengan menggunakan teori yang dikemukakan oleh Mahmudi (2010), yang sejalan dengan peningkatan kinerja yang sesuai dengan visi dan misi organisasi, dalam Manajemen Kinerja Sektor Publik.

Tabel 7. Rangkuman Hasil Tanggapan Responden Berdasarkan Dimensi pada Perspektif Pertumbuhan dan Pembelajaran

\begin{tabular}{|c|c|c|c|c|c|c|c|}
\hline \multirow{2}{*}{ No } & \multirow{2}{*}{ Dimensi } & \multicolumn{5}{|c|}{ Presentase Jawaban } & \multirow{2}{*}{$\mathbf{N}$} \\
\hline & & SS & $\mathbf{S}$ & CS & TS & STS & \\
\hline 1 & Ketercapaian & $47,51 \%$ & $28,68 \%$ & $16,94 \%$ & $5,76 \%$ & $1,11 \%$ & $100,00 \%$ \\
\hline 2 & Sarana & $40,05 \%$ & $31,52 \%$ & $19,64 \%$ & $6,98 \%$ & $1,81 \%$ & $100,00 \%$ \\
\hline 3 & Periode & $48,45 \%$ & $31,01 \%$ & $14,34 \%$ & $6,20 \%$ & $0,00 \%$ & $100,00 \%$ \\
\hline 4 & Pertimbangan sistematik & $37,98 \%$ & $30,23 \%$ & $22,74 \%$ & $8,53 \%$ & $0,52 \%$ & $100,00 \%$ \\
\hline 5 & Hukuman & $38,18 \%$ & $35,46 \%$ & $16,86 \%$ & $8,14 \%$ & $1,36 \%$ & $100,00 \%$ \\
\hline 6 & Motivasi & $49,80 \%$ & $30,62 \%$ & $9,11 \%$ & $8,92 \%$ & $1,55 \%$ & $100,00 \%$ \\
\hline \multirow[t]{3}{*}{7} & Akuntabilitas publik & $48,84 \%$ & $28,68 \%$ & $16,28 \%$ & $5,03 \%$ & $1,17 \%$ & $100,00 \%$ \\
\hline & & $310,81 \%$ & $216,20 \%$ & $115,91 \%$ & $49,56 \%$ & $7,52 \%$ & $700,00 \%$ \\
\hline & Jumlah & $44,40 \%$ & $30,89 \%$ & $16,56 \%$ & $7,08 \%$ & $1,07 \%$ & $100,00 \%$ \\
\hline
\end{tabular}

( sumber : hasil olahan penulis, 2014)

Hasil penelitian dapat disimpulkan bahwa dalam perspektif pertumbuhan dan pembelajaran pegawai kantor Sekertariat Daerah Kota Depok dinyatakan setuju bahwa produk layanan jasa yang dihasilkan sesuai dengan tujuan visi dan misi organisasi sehingga tujuan organisasi dapat dicapai secara maksimal serta dapat mengoptimalkan kinerja pegawai secara berkelanjutan.

Analisis Kinerja Manajerial pada perspektif pertumbuhan dan pembelajaran terkait pengembangan organisasi diperlukan untuk menggeser konsep dasar bagaimana organisasi bisa mencapai tujuannya, terdiri dari tiga unsur seperti :

a. Mencapai mobilisasi (achive mobilization). Merupakan usaha-usaha untuk menumbuhkan komitmen mulai dari tingkat individu, tim dan organisasi secara keseluruhan.

b. Menciptakan Visi (create vision). Menciptakan visi organisasi akan mempersiapkan arah organisasi pada umumnya dan pegawai pada khususnya untuk masa depan, sedangkan mobilisasi berusaha menciptakan segala potensi untuk pencapaian visi dan misi organisasi.

c. Membangun sistem pengukuran (build a measurement system). Merupakan langkah yang yang perlu dilakukan oleh pemimipin dengan menerjemahkan visi dan misi kedalam seperangkat ukuran-ukuran dan mendefinisikan tindakan-tindakan untuk mencapai target yang ditetapkan. System pengukuran ini mencakup aspek manajemen kiner di dalam suatu organisasi.

\section{Kerangka Kerja Balanced Scorecard}

Menurut Kaplan dan Norton $(2004,2010)$ kinerja organisasi tidak hanya diukur dari perspektif keuangan, namun perlu memasukkan perspektif pelanggan, proses bisnis internal dan pertumbuhan dan pembelajaran. Penilaian tersebut dijabarkan dalam kerangka kerja Balanced Scorecard sebagai berikut: 
Tabel 8.

Kerangka Kerja Pengembangan Balanced Scorecard

\begin{tabular}{|c|c|c|c|c|}
\hline No. & Agenda Startegis & Tujuan & Ukuran & Pendorong Kinerja Manajerial \\
\hline \multirow[t]{5}{*}{1} & Perspektif Keuangan & & & \\
\hline & Kinerja Lakip & \multirow[t]{4}{*}{$\begin{array}{l}\text { Laporan } \\
\text { Akuntabilitas } \\
\text { Kinerja In- } \\
\text { stansi Pemer- } \\
\text { intah (LAKIP) }\end{array}$} & \multirow[t]{4}{*}{$\begin{array}{l}\text { Peningkatan } \\
\text { kinerja Lakip }\end{array}$} & $\begin{array}{l}\text { a. Mengoptimalkan proses perencanaan } \\
\text { anggaran, sehingga dapat meminimali- } \\
\text { sir kesalahan dalm proses perencanaan } \\
\text { anggaran. }\end{array}$ \\
\hline & & & & $\begin{array}{l}\text { b. Menganggarkan kembali kegiatan-keg- } \\
\text { iatan yang belum terealisasi yang ma- } \\
\text { sih relevan untuk dilaksanakan ditahun } \\
\text { berikutnya. }\end{array}$ \\
\hline & & & & $\begin{array}{l}\text { c. Meningkatkan koordinasi antar bagian, } \\
\text { OPD lain, Pemerintah Propinsi Jawa } \\
\text { Barat dan Pemerintah Pusat. }\end{array}$ \\
\hline & & & & $\begin{array}{l}\text { d. Mengoptimalkan pelaksanaan monitor- } \\
\text { ing dan evaluasi kegiatan-kegiatan di } \\
\text { lingkup Sekertariat Daerah Kota Depok, } \\
\text { sehingga dapat diketahui keberhasilan, } \\
\text { kegagalan maupun keberlanjutan suatu } \\
\text { kegiatan. }\end{array}$ \\
\hline 2 & \multicolumn{4}{|l|}{ Perspektif Pelanggan } \\
\hline & Tangibles/ bukti fisik & \multirow[t]{6}{*}{$\begin{array}{l}\text { Tugas pokok } \\
\text { dan fungsi }\end{array}$} & $\begin{array}{l}\text { Penampilan } \\
\text { Pegawai Rapih }\end{array}$ & \multirow{3}{*}{$\begin{array}{l}\text { Achieve market focus, strategi mem- } \\
\text { fokuskan pada pasar merupakan usaha } \\
\text { untuk menghubungkan pola pikir or- } \\
\text { ganisasi secara keseluruhan pada ling- } \\
\text { kungannya. Sistem memusatkan pada } \\
\text { kepentingan pelanggan (konsumen) se- } \\
\text { hingga membawa pertumbuhan organ- } \\
\text { isasi. }\end{array}$} \\
\hline & Reability/ kehandalan & & $\begin{array}{l}\text { Proses pelay- } \\
\text { anan sesuai } \\
\text { kebutuhan }\end{array}$ & \\
\hline & $\begin{array}{l}\text { Responsiveness/ ket- } \\
\text { anggapan }\end{array}$ & & $\begin{array}{l}\text { Pelayanan/kemi- } \\
\text { traan }\end{array}$ & \\
\hline & Assurance/ jaminan & & Mutu layanan & \multirow[b]{2}{*}{$\begin{array}{l}\text { Invent new business, strategi menemu- } \\
\text { kan bisnis baru, merupakan strategi un- } \\
\text { tuk membangun kemampuan organisasi } \\
\text { melalui pendekatan kemitraan, merger } \\
\text { dan akuisisi dan melalui strategy ini } \\
\text { diharapkan membawa kehidupan baru } \\
\text { bagi organisasi. }\end{array}$} \\
\hline & Emphaty/perhatian & & $\begin{array}{l}\text { Sikap pegawai } \\
\text { yang ramah }\end{array}$ & \\
\hline & & & & $\begin{array}{l}\text { c. Change the rules through information } \\
\text { technology, pendekatan merubah aturan } \\
\text { melalui tehnologi informasi. Merupak- } \\
\text { an usaha memanfaatkan teknologi se- } \\
\text { bagai dasar untuk mencapai jalan baru } \\
\text { dalam menghadapi kompetisi. }\end{array}$ \\
\hline
\end{tabular}




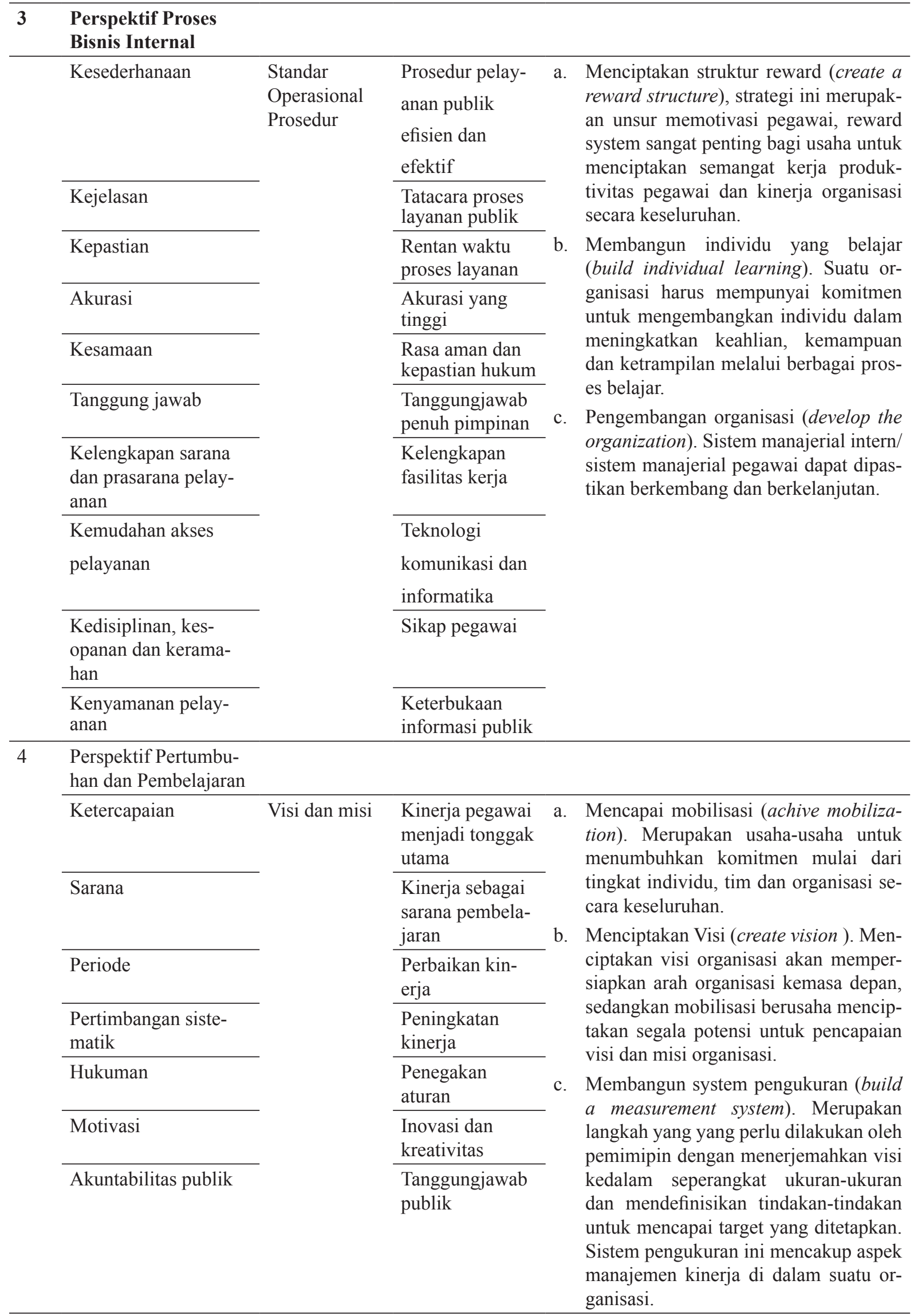




\section{SIMPULAN DAN SARAN}

\section{Simpulan}

1. Dalam perspektif keuangan, hasil penelitian yang dilakukan melalui pendekatan Balanced Scorecard dapat diterapkan pada kantor Sekertariat Daerah Kota Depok dimana Sekertarat Daerah Kota Depok yang mempunyai fungsi memberikan pelayanan kedinasan menunjukkan bahwa kinerja keuangan kantor Sekertariat Daerah Kota Depok menurut hasil LAKIP adalah sangat baik.

2. Dalam perspektif pelanggan, pegawai menghasilkan produk (layanan jasa) sudah sesuai dengan tugas pokok dan fungsi. Hasil penelitian terhadap perspektif pelanggan atau pengguna jasa layanan diukur dengan menggunakan dimensi tangibility, realibility, responsiveness, assurance dan empathy dimana dari keseluruhan nilai pada dimensi tersebut menunjukkan bahwa kinerja secara keseluruhan mendapatkan tanggapan responden pada skala setuju sehingga hasil interprestasi pada perspektif pelanggan adalah sangat kuat.

3. Dalam perspektif proses bisnis internal, pegawai telah dapat menghasilkan produk (layanan jasa) sesuai dengan SOP yang telah ditentukan. Hal ini dibuktikan dengan hasil tanggapan responden terhadap perspektif proses bisnis internal pada skala setuju dengan menggunakan indikator kesederhanaan, kejelasan, kepastian, akurasi, kesamaan, tanggungjawab, kelengkapan sarana dan prasaranan pelayanan, kedisiplinan, kesopanan dan keramahan serta kenyamanan pelayanan. Interprestasi pada perspektif pelanggan adalah sangat kuat.

4. Dalam perspektif pertumbuhan dan pembelajaran, dalam pegawai menghasilkan produk (layanan jasa) sudah sesuai dengan tujuan visi dan misi kantor. Diperoleh hasil penelitan bahwa kinerja pertumbuhan dan pembelajaran yang diukur menggunakan indikator ketercapaian, sarana, periode, pertimbangan sistematik, hukuman, motivasi dan akuntabilitas publik sudah sangat baik. Hal ini ditunjukkan dengan tanggapan responden pada skala setuju, sehingga hasil interprestasi pada perspektif pelanggan adalah sangat kuat.

5. Kerangka kerja Balanced Scorecard sebagai hasil pengukuran kinerja merupakan hasil penelitian yang dibentuk dalam strategi SDM untuk peningkatan kinerja pegawai kantor Sekertariat Daerah Kota Depok.

\section{Saran}

1. Pada perspektif keuangan secara keseluruhan, kinerja keuangan kantor Sekertariat Daerah Kota Depok bernilai baik, sehingga perlu untuk dipertahankan dan ditingkatkan pada tahun-tahun selanjutnya.

2. Pada perspektif pelanggan disarankan agar untuk mencapai tingkat pelayanan prima pada costumer satisfactor index maka kantor Sekertariat Daerah Kota Depok harus mampu melayani pelanggan secara memuaskan, baik dengan keterampilan dan kompetensi yang harus dimiliki oleh pegawai (attitude, penampilan, perhatian, tindakan, tanggung jawab, kecepatan, ketepatan, keramahan) maupun dengan memaksimalkan fasilitas-fasilitas penunjang (gedung, desain interior dan exterior serta peralatan/perlengkapan) yang mampu menimbulkan kenyamanan bagi pelanggan. Atau dengan kata lain dapat dikatakan bahwa titik tumpu pelayanan prima terletak pada kemampuan produsen jasa untuk memberian pelayanan secara optimal kepada konsumennya dengan menggabungkan kemampuan dari para pegawai dan memaksimalkan fasilitas-fasilitas penunjang. Sehingga penulis 
menyarankan kepada penelitian selanjutnya diharapkan dapat mencakup aspek pengguna jasa layanan yang lebih luas seperti masyarakat yang ingin memperoleh langsung layanan jasa pegawai kantor Sekertariat Daerah Kota Depok secara keseluruhan sehingga pengukuran pada perspektif pelanggan merujuk pada tugas pokok dan fungsi dapat diperoleh secara lebih optimal dan dan harus semaksimal mungkin mempertahankan bahkan meningkatkan customer satisfaction rate dari waktu ke waktu.

3. Pada perspektif proses bisnis internal, disarankan agar employee satisfaction index tercapai. Pegawai yang puas dan memiliki komitmen tinggi terhadap pekerjaan yang dilakukan akan meningkatkan produktivitas sehingga memiliki keterhubungan dengan layanan kepuasan pelanggan yang tentunya akan berdampak pada peningkatan mutu pelayanan yang semakin meningkat. Disatu sisi pihak manajemen dapat melakukan perbaikan sesuai masukan dan saran pegawai, yang pada akhirnya dapat meningkatkan kinerja organisasi sesuai dengan Standar Operasional Prosedur (SOP), khususnya terhadap indikatorindikator yang memperoleh nilai rendah yaitu melalui upaya pemberian pendidikan dan pelatihan khususnya kepada pegawai yang bertugas langsung dalam pelayanan.

4. Pada perspektif pertumbuhan dan pembelajaran, disarankan kepada organisasi untuk meningkatkan Kinerja (performance) pegawai dalam memenuhi tingkat pencapaian pelaksanaan suatu kegiatan/ program/ kebijakan dalam mewujudkan sasaran, tujuan, misi dan visi organisasi yang tertuang dalam strategic planning suatu organisasi. Dimana kinerja sering digunakan untuk menyebut prestasi atau tingkat keberhasilan individu maupun kelompok individu. Kinerja bisa diketahui hanya jika individu atau kelompok invidu tersebut mempunyai kriteria keberhasilan yang telah ditetapkan. Kriteria keberhasilan ini berupa tujuan-tujuan atau target-target tertentu yang hendak dicapai. Tanpa ada tujuan atau target, kinerja seseorang atau organisasi tidak mungkin dapat diketahui karena tidak ada tolok ukurnya. Sehingga strategi map disarankan dapat lebih dikembangkan pada penelitian selanjutnya.

5. Kerangka kerja Balanced Scorecard sebagai hasil pengukuran kinerja merupakan hasil penelitian yang diharapkan dan disarankan dapat di implementasikan sebagai strategi Sumber Daya Manusia (SDM) untuk peningkatan kinerja pegawai kantor Sekertariat Daerah Kota Depok.

\section{REFERENSI}

Body, Lawson; Jared Keengwe; Laurence Mukankusi; Abdou illia; Glenn Miler. 2008. "Egovernment Service Delivery Performance: an Adaptation of the BSC for The Public Sector”. Journal of Electronic Commerce di Organization. Vol. 6 (2) pp 11-28.

Federica, Farneti and James Guthrie. 2008. "BSC Development and Management of Public Sector Performance for Budget Users in Croatia International Conference Proceedings". Journal of Human Research Costing \& Accounting. Vol 12 (1).

Kaplan, R.S. \& Norton, D.P. 2004. The Balanced Scorecard: Translating Strategy into Action, Harvard Business School Press, Boston, MA.

Kaplan, Robert S dan Norton, David P 2010. The Strategy Focus Organization: How Balanced Scorecard Companies Thrive in the New Business Environment. Massachusetts: Harvard Business School Publishing Corporation. 
Mahmudi. 2010. Manajemen Kinerja Sektor Publik. Yogyakarta: Unit Penerbitan dan Percetakan Sekolah Tinggi Ilmu Manajemen YPKN.

Mahsun, Mohamad. 2009. Pengukuran Kinerja Sektor Publik. Yogyakarta: BPFE.

Maltz. A.C., Shenhar, A.J., Reilly, R.R.. 2004. Beyond the Balance Scorecard: Refining the Search for Organizational Success Measures Long Range Planning. The International Journal of Public Sector Management. Canada Social Science. Vol. 36 (2). pp. 187204.

Manville, G. 2007. Implementation a Balance Scorecard Framework in a not for Profit SME, International Journal of Productivity and Performance Management. Bradford. Vol. 56 (2). pp 162-169.

Mei, Jiang. 2013. Reconstruction of Balanced Scorecard in Chinese Local Goverments: Correction Model Based on Service Oreiented Goal Strategic Government. The International Journal of Public Sector Management. Canada Social Science. Vol. 9 (5). pp. 156-161.

Nothcott, Deryl. 2012. Using the Balance Scorecard to Manage the Performance of Public Sector Organizations. The International Journal of Management. Vol. 25 (3). pp 166191.

Parasuraman, Valarie A. Zeithaml, dan Leonard L. Berry, 2010. “A Conceptual Model of Service Quality and Its Implications for Future Research. Vournal of Marketing. pp 41-50

Sugiyono, 2010 ${ }^{\text {a). }}$ Metode Penelitian Bisnis, Bandung: Alfabeta.

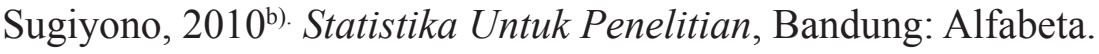

Verica, Budimir.; Mirjana, Jeleg Rugaz.; Mario Zupan. 2012. "BSC Development and Management of Public Sector Performance for Budget Users in Croatia". The International Conference Proceedings: 606-621. Zagreb: University of Zagreb. February 2012.

\section{PERATURAN PERUNDANGAN}

Republik Indonesia, Instruksi Presiden Republik Indonesia Nomor 7 Tahun 1999 tentang Laporan Akuntabilitas Instansi Pemerintah.

Republik Indonesia, Keputusan Menteri Dalam Negeri dan Otonomi Daerah Nomor 50 Tahun 2000 tentang Pedoman Susunan Organisasi Tata Kerja Perangkat Daerah.

Republik Indonesia, Keputusan Menteri Negara Pendayagunaan Aparatur Negara Republik Indonesia Nomor 63 Tahun 2003 Tentang Pedoman Umum Penyelenggaraan Pelayanan Publik.

Republik Indonesia, Peraturan Daerah Kota Depok Nomor 8 Tahun 2008 tentang Organisasi Perangkat Daerah dibentuknya Sekretariat Daerah Kota Depok tentang Rincian Tugas, Fungsi dan Tata Kerja Sekretariat Kota Depok. 